\title{
PERTIMBANGAN HAKIM TERHADAP PERKARA CERAI GUGAT SUAMI GHAIB DAN AKIBAT HUKUMNYA DI PENGADILAN AGAMA KARAWANG
}

\author{
Rd. Singgih Hasanul Baluqia, \\ Puti Priyana \\ Universitas Singaperbangsa Karawang \\ Email : hb.singgih@gmail.com, \\ puti.priyana@fh.unsika.ac.id
}

\begin{abstract}
Marriage is a sacred bond between a man and a woman as husband and wife. With the aim of creating a sakinah household, mawaddah wa rahmah. However, in reality there are many incompatibilities that happened between husband and wife in a journey of household, which in the end leads to not achieving the purpose of marriage which ends in divorce. There are many factors that trigger the occurrence of divorce, one of which is the disappearance of one party by leaving the other party without giving news for a long time and resulting in uncertainty about the status of the abandoned marriage. The purpose of this study is to find out and examine how judges consider divorce cases against unseen (ghaib) husbands and their legal consequences at the Karawang Religious Court. Research Methods in this scientific papers using normative juridical research methods. As well as using data collection techniques carried out using descriptive analysis techniques, with secondary data sources, which include primary legal materials such as laws and regulations relating to the rights of children and wives in divorce cases against unseen husbands, as well as secondary legal materials such as books., journals, articles, and other legal doctrines. The results of the research that have been carried out basically in the judge's decision on the divorce case with the unseen husband which is the basis for the judge's consideration is the absence of the defendant whose his existence are unknown, namely the waiting period or iddah for the Plaintiff is set for at least 90 (ninety) days from the verdict has permanent legal force as intended by Article 11 paragraph (1) and paragraph (3) of Act Number 1 of 1974 jo. Article 39 Government Regulation Number 9 of 1975 paragraph (1) letter (b) jo. Article 153 paragraph (2) letter (b) and Article 153 paragraph (4) Compilation of Islamic Law (KHI), and the issuance of a certificate of occultation from the local village.
\end{abstract}

\section{Keywords: Judge's Consideration, Divorced Lawsuit, Ghaib Husband}

\section{PENDAHULUAN}

Perkawinan merupakan suatu ikatan lahir batin antara seorang pria dengan seorang wanita sebagai suami isteri. Menciptakan rumah tangga yang Sakinah, Mawaddah wa Rahmah, merupakan tujuan dari perkawinan. Sedangkan, tujuannya dalam UndangUndang Perkawinan untuk menciptakan perkawinan yang kekal serta Bahagia sesuai 


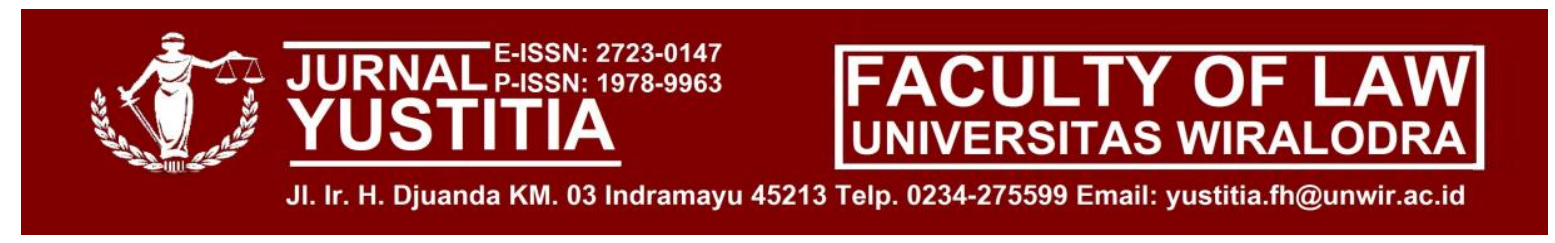

dengan ketuhanan, tujuan ini sama dengan yang ada pada KHI. Dalam hukum adat tujuan dari hal ini bisa berbeda-beda tergantung lingkungan masyarakat adatnya, biasanya tergantung pada agama yang dianut, apabila sudah dilakukan sesuai kepercayaan agamanya maka dianggap sah. ${ }^{1}$ Namun, tujuan dalam perkawinan tersebut tidak selalu berjalan sesuai dengan apa yang diharapkan, tidak jarang dalam suatu perkawinan yang sudah berjalan bertahun-tahun maupun yang belum lama melangsungkan perkawinan berakhir dengan perceraian.

Perceraian diatur dalam pasal 39 ayat (1) dan (2) Undang-Undang Nomor 16 Tahun 2019 tentang perubahan atas Undang-Undang Nomor 1 Tahun 1974 tentang Perceraian yang menyatakan :

"(1) Perceraian hanya dapat dilakukan di depan sidang pengadilan setelah pengadilan berusaha dan tidak berhasil mendamaikan kedua belah pihak.

(2) Untuk melakukan perceraian harus cukup alasan bahwa antara suami istri tidak akan dapat hidup rukun lagi sebagai suami istri."

Perceraian secara yuridis berarti putusnya perkawinan yang mengakibatkan putusnya hubungan sebagai suami istri. Mantan suami/istri mempunyai kedudukan hak dan kewajiban menurut pasal 41 huruf c Undang-Undang Nomor 16 Tahun 2019 tentang perubahan atas Undang-Undang Nomor 1 Tahun 1974 tentang Perkawinan menyatakan bahwa : "Pengadilan dapat mewajibkan kepada bekas suami untuk memberikan biaya penghidupan dan/atau menentukan sesuatu kewajiban bagi bekas isteri."

Perceraian dapat dilakukan dengan melewati gugatan pengadilan, dimana hakim akan bertindak sabagai perantara bagi suami istri atau kedua belah pihak yang berperkara, agar hak-hak dan kewajibannya terjamin. Untuk itu, Hakim diharuskan mendengarkan keterangan kedua belah pihak. Pada saat kedua belah pihak dipanggil di muka sidang mereka harus mendapatkan perlakuan yang sama, sehingga menghasilkan keputusan berdasarkan hukum yang tepat. Namun seringkali ketidakhadiran salah satu pihak menuntut hakim untuk menghasilkan keputusan tersendiri oleh pengadilan. Dalam perkara cerai gugat alasan ketidakhadiran tergugat (suami) salah satunya adalah tergugat yang tidak

\footnotetext{
${ }^{1}$ Tinuk Dwi Cahyani, Hukum Perkawinan, Universitas Muhammadiyah Malang UMM Press, Malang, 2020, hlm. 2 .
} 
diketahui keberadaannya (ghaib). Ketidakhadiran salah satu pihak menyebabkan putusan yang dikeluarkan oleh hakim disebut dengan istilah putusan verstek.

Verstek merupakan suatu keadaan apabila salah satu pihak tidak hadir dalam persidangan. Adapun pengertian putusan verstek ialah putusan yang dijatuhkan karena tergugat/termohon tidak pernah hadir meskipun telah dipanggil secara resmi, sedang penggugat hadir dan mohon putusan. ${ }^{2}$ Putusan verstek ini merupakam pengecualian dari acara persidangan biasa sebagai akibat ketidakhadiran tergugat atas alasan yang tidak sah. Putusan ini dapat berkekuatan hukum tetap apabila tidak ada upaya perlawanan (verzet).

Berdasarkan pengamatan yang ditemukan pada salah satu kasus perceraian yang terdapat di Pengadilan Agama Karawang terdapat perceraian akibat suami tidak hadir dalam proses persidangan. Gugatan yang dilakukan oleh seorang istri terhadap suaminya yang pergi meninggalkan istri tanpa adanya izin dan alasan yang sah, dan selama suami tidak pulang, suami tidak mengirim kabar serta tidak diketahui alamatnya yang jelas dan pasti di wilayah Indonesia.

Dalam gugatan tersebut dinyatakan bahwa suami meninggalkan istri sejak bulan agustus 2002 hingga saat ini, sampai istri menghadap kepada kepala kelurahan untuk diterbitkannya surat keterangan ghoib Nomor: 474.1/688/Kel. tertanggal 10 November 2020. Dalam gugatan tersebut terdapat fakta berdasarkan para saksi bahwa selain suami yang pergi/hilang (ghaib/mafqud), juga terdapat adanya unsur suami tidak memberi nafkah lahir dan batin, serta menelantarkan istri dan anak dibawah umur selama kepergian suami sampai saat diputuskan/dikabulkan nya gugatan tersebut oleh Majelis Hakim.

Berdasarkan uraian yang telah dijelaskan diatas, peneliti tertarik untuk melakukan penelitian dengan judul "PERTIMBANGAN HAKIM TERHADAP PERKARA CERAI GUGAT SUAMI GHAIB DAN AKIBAT HUKUMNYA DI PENGADILAN AGAMA KARAWANG".

\section{IDENTIFIKASI MASALAH}

Mengacu pada penjabaran latar belakang seperti di atas, maka dalam penelitian ini penulis akan memfokuskan pada identifikasi permasalahan sebagai berikut: "Bagaimana

\footnotetext{
A. Mukti Arto, Praktek Perkara Perdata pada Pengadilan Agama, cet. Ke-6, Pustaka Pelajar, Yogyakarta, 2005, hlm. 25.
} 


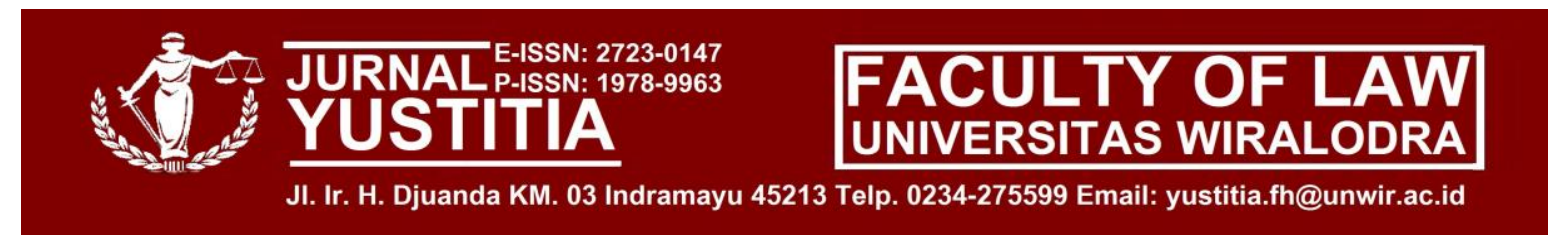

Aspek Hukum Perkara Cerai Gugat Suami Ghaib dan Akibat Hukumnya di Pengadilan Agama Karawang?”.

\section{METODE}

Metode penelitian adalah langkah yang dilakukan dalam menambah kemampuan para ilmuwan untuk mengadakan atau melaksanakan penelitian secara lebih atau lebih lengkap ${ }^{3}$. Metode penelitian bertujuan untuk memperoleh data mengenai hubungan antara suatu gejala dengan gejala yang lain dengan melakukan pendekatan penelitian apa, spesifikasi penelitian yang seperti apa serta jenis dan sumber data.

Pada penelitian ini, penulis menggunakan metode pendekatan yuridis normatif. Yuridis Normatif yakni penelitian hukum yang mencangkup penelitian terhadap normanorma hukum yang terdapat dalam undang-undang, asas-asas hukum, penelitian terhadap sistematika hukum penelitian terhadap taraf sinkronisasi hukum, penelitian sejarah hukum ${ }^{4}$.

Pada metode pendekatan ini mengkaji permasalahan hukum berdasarkan aturan normatif yang dikaitkan dengan kondisi yang berkembang di masyarakat. Pendekatan yang dilakukan dalam penelitian ini melihat suatu kasus perceraian dengan putusan verstek di Pengadilan Agama Karawang.

Berdasarkan pasal 38 Undang-Undang Nomor 16 Tahun 2019 tentang perubahan atas Undang-Undang Nomor 1 Tahun 1974 Tentang Perkawinan menyebutkan bahwa salah satu sebab putusnya perkawinan yaitu karena Perceraian. Perceraian adalah pengakhiran suatu perkawinan karena sesuatu sebab dengan keputusan hakim atas tuntutan dari salah satu pihak atau kedua belah pihak dalam perkawinan ${ }^{5}$.

Dalam hukum Indonesia dibedakan cara mengajukan gugatan cerai. Bagi yang beragama Islam, gugatan cerai (oleh istri) dan permohonan talak (oleh suami) diajukan ke pengadilan agama. Sedangkan, bagi yang beragama selain Islam, gugatan cerai diajukan ke pengadilan negeri. Cara mengajukan gugatan perceraian diatur dalam pasal 20 Peraturan Pemerintah Nomor 9 Tahun 1975 Tentang Pelaksanaan Undang-Undang Nomor 1 Tahun 1974 Tentang Perkawinan Menyatakan Bahwa:

\footnotetext{
${ }^{3}$ Soerjono Soekanto, Pengantar Penelitian Hukum, Universitas Indonesia (UI-Press). Jakarta, 2014, hlm. 7.

${ }^{4}$ Ibid

${ }^{5}$ P.N.H. Simanjuntak, Pokok-pokok Hukum Perdata Indonesia, Jakarta: Pustaka Djambatan, 2007, hlm. 53.
} 
(1) Gugatan perceraian diajukan oleh suami atau isteri atau kuasanya kepada Pengadilan yang daerah hukumnya meliputi tempat kediaman tergugat.

(2) Dalam hal tempat kediaman tergugat tidak jelas atau tidak diketahui atau tidak mempunyai tempat kediaman yang tetap, gugatan perceraian diajukan kepada Pengadilan ditempat kediaman penggugat.

(3) Dalam hal tergugat bertempat kediaman diluar negeri, gugatan perceraian diajukan kepada Pengadilan ditempat kediaman penggugat. Ketua Pengadilan menyampaikan permohonan tersebut kepada tergugat melalui Perwakilan Republik Indonesia setempat

Sesuian dengan peraturan perundang-undangan yang berlaku gugatan perceraian dapat diajukan kepada pengadilan, dimana hakim akan bertindak sebagai perantara bagi kedua-belah pihak, sehingga hak-hak dan kewajiban warga negara terjamin. Sesuai dengan ketentuan pasal 178 HIR, Pasal 189 RBG apabila pemeriksaan perkara selesai, Majelis Hakim karena jabatannya melakukan musyawarah untuk mengambil putusan yang akan dijatuhkan ${ }^{6}$.

Putusan dapat ditinjau dari berbagai segi, salah satunya putusan yang ditinjau dari aspek kehadiran para pihak yakni putusan gugatan gugur, putusan verstek, dan putusan contradictoir. Sering kali ada kekeliruan yang menyamakan putusan verstek dengan kontradiktor. Padahal antara keduanya terdapat perbedaan yang fundamental. Pengambilan putusan verstek mesti didasarkan atas ketidakhadiran tergugat pada sidang pertama tanpa alasan yang sah. Sedang putusan kontradiktor, ketidakhadiran itu terjadi pada saat putusan diucapkan.

Mengenai pengertian verstek, tidak terlepas kaitannya dengan fungsi beracara dan penjatuhan putusan atas perkara yang disengketakan, yang memberi wewenang kepada hakim menjatuhkan putusan tanpa hadirnya penggugat atau tergugat. Sehubungan dengan itu, persoalan verstek tidak terlepas kaitannya dengan ketentuan Pasal 124 HIR (Pasal 77 Rv) dan Pasal 125 ayat (1) HIR (Pasal 73 Rv). 7 Maksud utama sistem verstek dalam hukum acara adalah untuk mendorong para pihak menaati tata tertib beracara, sehingga proses pemeriksaan penyelesaian perkara terhindar dari anarki atau kesewenangan ${ }^{7}$.

\footnotetext{
${ }^{6}$ M. Yahya Harahap, Hukum Acara Perdata, Edisi kedua, Jakarta: Sinar Grafika, 2018, hlm. 797.

${ }^{7}$ Ibid, hlm. 381-382.
} 


\section{HASIL DAN PEMBAHASAN}

Perceraian ialah putusnya ikatan lahir batin antara suami dan istri yang mengakibatkan berakhinya hubungan keluarga (rumah tangga) antara suami dan istri tersebut. Kasus perceraian di Indonesia menjadi masalah serius yang harus diperhatikan. Angka kasus perceraian diberbagai daerah sangat mengkhawatirkan, khususnya kasus perceraraian di Kota Karawang.

Panitera Hukum Pengadilan Agama Karawang Abdul Hakim mengatakan, dari januari hingga tanggal 9 Maret 2020, tercatat 648 pasangan bercerai di Pengadilan Agama Karawang. Sedangkan dalam sehari, sedikitnya 30 orang mengajukan perkara perceraian. Selama lima tahun terakhir angka perceraian di Karawang semakin tinggi. Sepanjang tahun 2019 tercatat 4.409 pasangan yang bercerai. Jumlah tersebut lebih banyak dibanding tahun 2018, sebanyak 2.985 kasus perceraian. Abdul hakim menuturkan, dari banyaknya angka perceraian tahun 2019, mayoritas ialah cerai gugat dari pihak istri berkisar 3.329 kasus, sedangkan kasus cerai talak tercatat 1.080 perkara. Adapun factor penyebab dari banyaknya perceraian, diantaranya factor ekonomi, pertengkaran, perselingkuhan, hingga kekerasan dalam rumaht tangga. Menurutnya kesulitan ekonomi menjadi factor utama penyebab tingginya angka perceraian di Karawang. Tercatat selama tahun 2019, terhitung 2.142 pasangan suami istri bercerai karena kesulotan ekonomi ${ }^{8}$.

Berdasarkan pernyataan diatas, faktor utama penyebab terjadinya perceraian karena kesulitan ekonomi, perceraian tidak hanya dapat dilakuakan oleh laki-laki saja tetapi perempuan juga dapat mengajukan gugatan perceraian yaitu disebut dengan cerai gugat. Cerai gugat adalah sesuatu yang bertentangan dengan tujuan perkawinan. Namun demikian, cerai gugat bisa dilakukan jika dalam keadaan terpaksa untuk menghindarkan bahaya yang lebih besar. Hal ini sesuai dengan kaidah fiqhiyah yang menegaskan jika seseorang dihadapkan kepada suatu dilema, maka dibenarkan untuk memilih melakukan kemudharatan yang paling ringan di antara beberapa kemudharatan yang sedang dihadapinya.

\footnotetext{
8 Wawancara Panitera Pengadilan Agama Karawang oleh Raka, Tiga Bulan Ada 648 Janda Baru, 2020, Diakses pada laman https://radarkarawang.id/metropolis/tiga-bulan-ada-648-jandabaru/ pada tanggal 10 Juli 2021 pukul 23.45 WIB.
} 
Gugatan perceraian diajukan oleh istri atau kuasanya pada Pengadilan Agama, yang daerah hukumnya mewilayahi tempat tinggal penggugat kecuali istri meninggalkan tempat kediaman bersama tanpa ijin suami. Dalam hal tergugat bertempat kediaman di luar negeri, Ketua Pengadilan Agama memberitahukan gugatan tersebut melalui Perwakilan Republik Indonesia setempat ${ }^{9}$. Sama hal nya apabila suami meninggalkan istrinya selama 2 tahun berturut-turut, tanpa adanya kabar dan tidak diketahui keberadaannya, dan telah dilakukan upaya pemanggilan melalui papan pengumuman Pengadilan Agama dan disiarkan dalam surat kabar. Dalam hal tersebut istri dapat mengajukan gugatan ghoib dengan memenuhi syarat yang sudah ditentukan.

Cerai ghaib juga disebut cerai mafqud. Mafqud dalam bahasa Arab secara harafiah bermakna hilang. Sesuatu dikatakan hilang apabila tidak ada atau lenyap ${ }^{10}$. Sedangkan, mafqud menurut istilah syara' adalah orang yang pergi dari tempat tinggalnya dan tidak dapat diketahui apakah dia masih hidup ataukah telah meninggal dunia $^{11}$. Dalam hukum Islam ada fasakh karena suami ghaib (al mafqud), yaitu suami meninggalkan tempat tetapnya dan tidak diketahui ke mana perginya, serta tempat tinggalnya dalam waktu yang lama. Hal ini tentu saja akan menyulitkan kehidupan istri yang ditinggalkan, terutama bila suami tidak meninggalkan susatu (nafkah) bagi kehidupannya dan anak-anaknya ${ }^{12}$. Menurut kamus istilah fikih mafqud adalah orang yang hilang dan menurut zahirnya tertimpa kecelakaan, seperti orang yang meninggalkan keluarganya pada waktu malam atau siang atau keluar rumah untuk menjalankan sholat atau ke satu tempat yang dekat kemudian tidak kembali lagi atau hilang di dalam kancah pertempuran ${ }^{13}$.

Dari beberapa pengertian tersebut, dapat diambil simpulan bahwa yang dimaksud dengan cerai ghaib (cerai mafqud) menurut hukum Islam adalah perceraian yang dimana salah satu pihaknya sudah lama pergi meninggalkan tempat tinggalnya dan tidak diketahui domisilinya serta tidak pula diketahui hidup dan matinya.

\footnotetext{
9 Salim HS, Pengantar Hukum Perdata Tertulis (BW), Sinar Grafika, Jakarta, 2003, hlm.80

${ }^{10}$ Muhammad Ali As-Shabuni, Hukum Waris Dalam Syari'at Islam, Diponegoro, Surakarta, 1992, hlm. 235.

${ }^{11}$ Dian Khairul Umam, Fiqih Mawaris, Pustaka Setia, Bandung, 1999, hlm. 214.

12 Abdul Ghofur Anshori, Op. Cit, hlm. 143.

${ }^{13}$ M. Abdul Mujieb, Mabruri Tholhah dan Syafi'ah AM, Kamus Istilah Fikih, Pustaka Firdaus, Jakarta, 1994, hlm. 50.
} 
Dalam hal ini hakim dengan keyakinannya dapat menetapkan mafqudnya seseorang itu dengan berbagai pendapat yang diyakininya sebagai dasar dan landasan dalam menetapkan orang tersebut masih hidup ataukah sudah meninggal. Menurut istilah mafqud bisa diterjemahkan dengan al-ghoib. Kata ini secara bahasa memiliki arti gaib, tiada hadir, bersembunyi, mengumpat. Hilang dalam hal ini terbagi menjadi dua macam, yaitu: ${ }^{14}$

1. Hilang yang tidak terputus karena diketahui tempatnya dan ada berita atau informasi tentangnya.

2. Hilang yang terputus, yaitu yang sama sekali tidak diketahui keberadaannya serta tidak ditemukan informasi tentangnya.

Pertimbangan Hukum Hakim dapat digunakan dalam dua arti yaitu dalam arti luas dan sempit. Dalam arti luas, pertimbangan hukum hakim berkaitan dengan proses psikologis yang dilakukan hakim untuk sampai pada putusan atas kasus yang dihadapinya, sedangkan pertimbangan hukum hakim dalam arti sempit berkaitan dengan argumentasi yang melandasi suatu keputusan, artinya menyangkut kajian logika dari suatu putusan, yaitu hubungan antara pertimbangan dan putusan, serta ketepatan alasan atau pertimbangan yang mendukung putusan tersebut.

Argumentasi sebagai dasar dan cara penemuan hukum hakim yang juga dijadikan hakim sebagai pertimbangan. Argumentasi Hukum, adalah "alasan berupa uraian penjelasan yang diuraikan secara jelas, berupa serangkaian pernyataan secara logis, untuk memperkuat atau menolak suatu pendapat, pendirian atau gagasan, berkaitan dengan asas hukum, norma hukum dan peraturan hukum konkret, serta sistem hukum dan penemuan hukum".

Suatu argumentasi bermakna, hanya dibangun atas dasar logika, adalah suatu "conditio sine qua non" agar suatu keputusan dapat diterima, yakni apabila didasarkan pada proses nalar, sesuai dengan sistem logika formal yang merupakan syarat mutlak dalam berargumentasi. Argumen-argumen tersebut harus dirumuskan dan disusun dengan cermat, runtut, sistimatik dengan menggunakan bahasa hukum yang baik dan benar. Dasar pertimbangan majelis hakim terhadap putusan nerceraian secara ghaib di Pengadilan Agama Karawang, adanya keterangan dari Kelurahan

\footnotetext{
${ }^{14}$ Mahmud Yunus, Kamus Arab Indonesia, Yayasan penyelenggara Penterjemah/Penafsir Al-Qur'an, Jakarta,
} 1973, hlm. 30. 
tempat tinggal Pemohon atau Penggugat vang menvatakan bahwa suami atau istri Pemohon atau Penggugat telah pergi dari kediaman mereka dengan tidak memberitahukan aiamat yang Jeias dimana keberadaanya. Atas dasar itulah pihak Pemohon atau Penggugat dapat mengajukan gugatan secara ghaib.

Pada perkara perceraian secara ghaib maka proses persidangan akan dimuiai 4 (empat) bulan seteiah gugatan atau permohonan di daftarkan atau mendapatkan nomor regisier perkara. dlkarenakan seiama 4 bulan lersebut, pihak suami atau isteri yang telah pergi meninggalkan kediamannya tersebut akan diumumkan melalui pengumuman Pengadilan Agama Karawang, setelah 4 bulan tidak juga ada berita atau kabamya barulah proses persidangan digelar dengan langsung menghadirkan pihak saksi dari pemohon atau penggugat.

Pertimbangan Hakim didalam Putusan Pengadilan Agama Karawang (Nomor 3625/Pdt.G/2020/PA.Krw) adalah bahwa meskipun tergugat sudah dipanggil secara resmi dan patut, tergugat tidak datang dalam persidangan dan ketidakhadiran tergugat tersebut tidak disebabkan oleh suatu halangan yang sah, hal tersebut diharuskan diperiksa secara verstek. Pada putusan verstek berkaitan dengan ketentuan pasal 125 HIR yaitu putusan yang dijatuhkan tanpa hadirnya tergugat dapat dikabulkan sepanjang berdasarkan hukum dan beralasan.

Apabila Termohon (tergugat) meninggalkan tempat kediaman yang telah disepakati bersama tanpa izin Pemohon (penggugat) maka permohonan harus diajukan kepada pengadilan agama yang daerah hukumnya meiiputi tempai kediaman Pemohon (penggugat). Gugatan ghaib ini dimaksudkan adalah ketika terjadi salah satu pihak suami atau isteri (tergugat) meninggalkan salah satu (penggugat) pihak. hingga beberapa bulan dan tidak diketahui keberadaanya secara pasti, namun masih diperkirakan daiam wiiayah Negara Kesatuan Repuhlik Indonesia.

Dalam Putusan Pengadilan Agama Karawang (Nomor 3625/Pdt.G/2020/PA. Krw), Majelis membebani Penggugat untuk membuktikan dalil-dalil gugatannya, bahwa dari posita Penggugat memohon agar dijatuhkan talak satu bain shugro tergugat terhadap penggugat dengan alasan karena dalam rumah tangga antara penggugat dengan tergugat telah terjadi perselisihan dalam rumah tangga. Penggugat sudah memenuhi untuk membuktikan dalil-dalil gugatannya dengan mengajukan alat bukti surat P.1 dan P.2 serta 2 (dua) orang saksi. Rumah tangga penggugat dan 
tergugat awalnya rukun dan harmonis, namun sejak sekitar bulan Mei 2002 mulai tidak rukun sering terjadi perselisihan dan pertengkaran yang disebabkan karena tergugat kurang memberikan nafkah. Bahwa hal ini bersesuaian dan cocok antara saksi I dan saksi II dengan penggugat dan keterangan kedua orang saksi tersebut memenuhi Pasal 171 dan Pasal 172 HIR. Akibat dari pertengkaran tersebut, Penggugat dengan Tergugat telah berpisah tempat tinggal sejak bulan Agustus 2002 atau selama kurang lebih 19 (Sembilan belas) tahun sampai dengan surat putusan ini dikeluarkan, tergugat meninggalkan penggugat dengan tidak diketahui keberadaannya.

Berkaitan dengan ini sesuai dengan penjelasan Pasal 39 ayat (2) huruf f No. 1 Tahun 1974 jo. Pasal 19 huruf (f) PP No. 9 Tahun 1975 jo. Pasal 116 huruf (f) Kompilasi Hukum Islam yang menyatakan bahwa Antara suami dan istri terus terjadi perselisihan dan pertengkaran dan tidak ada harapan akan hidup rukun lagi dalam rumah tangga.

Berdasarkan pertimbangan tersebut, maka Majelis Hakim pada putusan Nomor 3625/Pdt.G/2020/PA.Krw berpendapat bahwa karena perselisihan dan pertengkaran dinyatakan terbukti dan menyebabkan mereka sudah tidak dapat rukun lagi sebagai suami isteri, meskipun pihak keluarga telah berupaya merukunkan tetapi tidak berhasil, maka sudah tidak efektif untuk mempertahankan rumah tangga Penggugat dan Tergugat, karena sudah tidak sesuai dengan tujuan perkawinan itu sendiri, membentuk keluarga bahagia lahir dan batin yang sakinah, mawaddah dan rahmah sebagaimana ditegaskan dalam Al Qur'an Surat Ar Ruum ayat 21 dan Pasal 1 Undang-Undang Nomor 1 tahun 1974, sebagaimana telah diubah dengan UndangUndang Nomor 16 Tahun 2019, tentang perubahan atas Undang-Undang Nomor 1 Tahun 1974, tentang Perkawinan.

Unsur-unsur alasan perceraian berdasarkan Pasal 19 huruf (b) Peraturan Pemerintah Nomor 9 Tahun 1975, jo Pasal 116 huruf (b) Kompilasi Hukum Islam, telah terpenuhi dan oleh karenanya Majelis Hakim berkesimpulan bahwa Penggugat telah mempunyai cukup alasan untuk melakukan perceraian. Berdasarkan ketentuan Pasal 39 ayat (2) Undang- Undang Nomor 1 Tahun 1974, sebagaimana telah diubah dengan Undang-Undang Nomor 16 Tahun 2019, tentang Perubahan Atas UndangUndang Nomor 1 Tahun 1974, tentang Perkawinan, gugatan Penggugat a quo telah 
beralasan dan tidak melawan hukum, sehingga gugatan Penggugat untuk bercerai dengan Tergugat patut untuk dikabulkan dengan menjatuhkan talak satu bain shughra Tergugat kepada Penggugat.

Kemudian Tergugat tidak pernah datang menghadap di muka sidang dan tidak mengutus orang lain selaku wakil atau kuasanya meskipun ia telah dipanggil dengan pataut maka dengan didasarkan kepada ketentuan pasal 126 HIR, Tergugat patut dinyatakan tidak hadir dan gugatan Penggugat dikabulkan dengan verstek. Karena perceraian yang dijatuhkan oleh Pengadilan, termasuk kedalam kategori talak satu bain sughraa, maka sesuai maksud Pasal 119 ayat (1) dan (2) Kompilasi Hukum Islam (KHI), antara Penggugat dan Tergugat tidak diperbolehkan rujuk kembali, terkecuali dengan akad nikah baru, meskipun masih dalam masa iddah.

Berdasarkan pada pertimbangan tersebut, masa tunggu atau iddah bagi Penggugat ditetapkan selama sekurang-kurangnya 90 (sembilan puluh) hari terhitung sejak putusan mempunyai kekuatan hukum tetap sebagaimana maksud pasal 11 ayat (1) dan ayat (3) Undang-Undang Nomor 1 Tahun 1974 jo. Pasal 39 PeraturanPemerintah Nomor 9 Tahun 1975 ayat (1) huruf (b) jo. Pasal 153 ayat (2) huruf (b) dan Pasal 153 ayat (4) Kompilasi Hukum Islam (KHI). Pada dasarnya dalam putusan hakim perkara cerai gugat dengan suami ghaib yang menjadi dasar pertimbangan hakim adalah ketidakhadiran tergugat yang tidak diketahui keberadaannya serta sudah diterbitkannya surat keterangan ghaib dari kelurahan setempat.

\section{PENUTUP}

\section{A. Simpulan}

Terlihat pada dasarnya dalam putusan hakim perkara cerai gugat dengan suami ghaib yang menjadi dasar pertimbangan hakim adalah ketidakhadiran tergugat yang tidak diketahui keberadaannya, yaitu masa tunggu atau iddah bagi Penggugat ditetapkan selama sekurang-kurangnya 90 (sembilan puluh) hari terhitung sejak putusan mempunyai kekuatan hukum tetap sebagaimana maksud pasal 11 ayat (1) dan ayat (3) Undang-Undang Nomor 1 Tahun 1974 jo. Pasal 39 Peraturan Pemerintah Nomor 9 Tahun 1975 ayat (1) huruf (b) jo. Pasal 153 ayat (2) huruf (b) 
dan Pasal 153 ayat (4) Kompilasi Hukum Islam (KHI). serta sudah diterbitkannya surat keterangan ghaib dari kelurahan setempat.

\section{B. Saran}

Supaya dapat diperhatikan lagi, bahwa ketidakhadiran tergugat perlu dipastikan lebih lanjut, apakah ketidakhadiran tersebut disebabkan kesengajaan dari pihak tergugat dan sudah menerima surat panggilan siding secara patut, atau memang sengaja disembunyikan pihak lain sehingga pihak tergugat tidak mengetahui adanya surat undangan siding, sehingga pihak tergugat tidak datang untuk menghadiri sidang.

\section{DAFTAR PUSTAKA}

\section{A. Buku}

Tinuk Dwi Cahyani, Hukum Perkawinan, Universitas Muhammadiyah Malang UMM Press. Malang, 2020,

Mukti Arto, Praktek Perkara Perdata pada Pengadilan Agama, cet. Ke-6, Pustaka Pelajar, Yogyakarta, 2005

Soerjono Soekanto, Pengantar Penelitian Hukum, Universitas Indonesia (UI-Press). Jakarta, 2014.

P.N.H. Simanjuntak, Pokok-pokok Hukum Perdata Indonesia, Jakarta: Pustaka Djambatan, 2007.

M. Yahya Harahap, Hukum Acara Perdata, Edisi kedua, Jakarta: Sinar Grafika, 2018.

Salim HS, Pengantar Hukum Perdata Tertulis (BW), Sinar Grafika, Jakarta, 2003.

Muhammad Ali As-Shabuni, Hukum Waris Dalam Syarieeat Islam, Diponegoro, Surakarta, 1992, hlm. 235.

Dian Khairul Umam, Fiqih Mawaris, Pustaka Setia, Bandung, 1999.

M. Abdul Mujieb, Mabruri Tholhah dan Syafieeah AM, Kamus Istilah Fikih, Pustaka Firdaus, Jakarta, 1994.

Mahmud Yunus, Kamus Arab Indonesia, Yayasan penyelenggara Penterjemah/Penafsir Al-Qureean, Jakarta, 1973. 